\title{
Soil biochemistry and microbial activity in vineyards under conventional and organic management at Northeast Brazil
}

\author{
Nicácio de Oliveira Freitas ${ }^{1}$; Adriana Mayumi Yano-Melo²; Fábio Sérgio Barbosa da Silva \\ Natoniel Franklin de Melo ${ }^{4}$; Leonor Costa Maia ${ }^{1 *}$ \\ ${ }^{1}$ UFPE - Depto. de Micologia, Av. Nelson Chaves, s/n - 50670-420 - Recife, PE - Brasil. \\ ${ }^{2}$ UNIVASF - Colegiado de Zootecnia, Av. José de Sá Maniçoba, s/n - 56304-917 - Petrolina, PE - Brasil. \\ ${ }^{3} U P E$ - Faculdade de Formação de Professores de Petrolina, BR 203, km 2 - 56300-000 - Petrolina, PE - Brasil. \\ ${ }^{4}$ Embrapa Semi-Árido - C.P. 23 - 56302-970 - Petrolina, PE - Brasil. \\ *Corresponding author <leonorcmaia@yaboo.com.br>
}

\begin{abstract}
The São Francisco Submedium Valley is located at the Brazilian semiarid region and is an important center for irrigated fruit growing. This region is responsible for $97 \%$ of the national exportation of table grapes, including seedless grapes. Based on the fact that organic fertilization can improve soil quality, we compared the effects of conventional and organic soil management on microbial activity and mycorrhization of seedless grape crops. We measured glomerospores number, most probable number (MPN) of propagules, richness of arbuscular mycorrhizal fungi (AMF) species, AMF root colonization, EE-BRSP production, carbon microbial biomass (C-MB), microbial respiration, fluorescein diacetate hydrolytic activity (FDA) and metabolic coefficient $\left(q \mathrm{CO}_{2}\right)$. The organic management led to an increase in all variables with the exception of EE-BRSP and $q \mathrm{CO}_{2}$. Mycorrhizal colonization increased from $4.7 \%$ in conventional crops to $15.9 \%$ in organic crops. Spore number ranged from 4.1 to 12.4 per $50 \mathrm{~g}^{-1}$ soil in both management systems. The most probable number of AMF propagules increased from $79 \mathrm{~cm}^{-3}$ soil in the conventional system to $110 \mathrm{~cm}^{-3}$ soil in the organic system. Microbial carbon, $\mathrm{CO}_{2}$ emission, and FDA activity were increased by 100 to $200 \%$ in the organic crop. Thirteen species of AMF were identified, the majority in the organic cultivation system. Acaulospora excavata, Entrophospora infrequens, Glomus sp.3 and Scutellospora sp. were found only in the organically managed crop. S. gregaria was found only in the conventional crop. Organically managed vineyards increased mycorrhization and general soil microbial activity.

Key words: Vitis vinifera L., arbuscular mycorrhizal fungi, semiarid, soil microbial activity, sustainable agriculture
\end{abstract}

\section{Atividade bioquímica e microbiológica do solo em videiras sob manejo orgânico e convencional no Nordeste do Brasil}

\begin{abstract}
RESUMO: O Vale do Submédio São Francisco é localizado na região do semi-árido brasileiro, sendo um importante centro da fruticultura irrigada, responsável por $97 \%$ da exportação nacional de uvas de mesa, incluindo as uvas sem sementes. Baseado no fato de que a fertilização orgânica pode melhorar a qualidade do solo, comparou-se o efeito do manejo orgânico e convencional sobre a atividade microbiana do solo e o estado micotrófico de videiras produtoras de uvas sem sementes. Foi avaliado o número de glomerosporos, número mais provável de propágulos (NMP), riqueza de espécies de fungos micorrízicos arbusculares (FMA), colonização de FMA, produção de PSRGFE, carbono da biomassa microbiana $(\mathrm{C}-\mathrm{BM})$, respiração microbiana, atividade de hidrólise do diacetato de fluoresceína (FDA) e quociente metabólico $\left(q \mathrm{CO}_{2}\right)$. O manejo orgânico aumentou todas as variáveis, com exceção da PSRG-FE e do $q \mathrm{CO}_{2}$. A colonização micorrízica foi $4.7 \%$ no cultivo convencional e $15.9 \%$ no orgânico. O número de esporos variou de 4.1 a 12.4 por $50 \mathrm{~g}^{-1}$ solo em ambos os sistemas de manejo. O NMP de propágulos de FMA foi de $79 \mathrm{~cm}^{-3}$ solo no sistema convencional e $110 \mathrm{~cm}^{-3}$ solo no sistema orgânico. O carbono microbiano, a emissão de $\mathrm{CO}_{2}$ e a atividade do FDA apresentaram incrementos de 100 a 200\% no cultivo orgânico. Treze espécies de FMA foram identificadas, a maioria no sistema orgânico. Acaulospora excavata, Entrophospora infrequens, Glomus sp.3 e Scutellospora sp. foram registradas apenas na cultura orgânica; S. gregaria foi exclusiva no cultivo convencional. O cultivo orgânico dos parreirais favorece a micorrização e a atividade microbiana do solo.

Palavras-chave: Vitis vinifera L., fungos micorrízicos arbusculares, atividade microbiana do solo, semi-árido, agricultura sustentável
\end{abstract}

\section{Introduction}

Soil microorganisms have an important role in ecological processes such as the nutrient cycling (Marshall, 2000; Nannipieri et al., 2003). Organic fertilization is important for soil microbial activity (Fernandes et al., 2005; Truu et al., 2008) because it improves soil's quality due to increase on avail- ability of organic matter which benefits physical, chemical and microbiological soil properties. This includes soil aggregation, aeration, and fertility levels, providing energetic substrates that potentially can be degraded by the edaphic microbiota, increasing the oxidative metabolism (Bettiol et al., 2002; Fernandes et al., 2005; Sampaio et al., 2008). However, the chemical products used in the conventional systems 
besides contaminating natural resources can suppress the soil microbial activity, what makes the system less sustainable and more dependent from agricultural inputs (Anaya, 1999; Bengtsson et al., 2005).

Arbuscular mycorrhizal fungi (AMF) live in a mutualistic association with roots of most plant species. This association improves the uptake of mineral nutrients by the plants, which also improves the nutritional status of the plant host and increases the crop productivity. AMF also interact with other rhizosphere organisms contributing for the equilibrium, quality and fertility of soils mainly through the stabilizing action of the mycelium network (Jeffries et al., 2003; Miyauchi et al., 2008; Srivastava et al., 2007). Higher AMF activity has been reported in agrosystems where mineral fertilizers were substituted by organic fertilizers (Mäder et al., 2000; Purin et al., 2006). Studies regarding the impact of organic versus conventional systems on AMF activity have the potential to increase the knowledge on biotechnological application of these fungi (Ryan et al., 2000; Ryan and Graham, 2002).

The São Francisco Submedium Valley is located at the Brazilian semiarid region and represents an important center of production of irrigated fruits. This area accounts for $97 \%$ of the produced table grapes (Vitis vinifera L.) that are exported. One of the main varieties of interest is the seedless grape whose production has increased in the past decade (Silva and Correia, 2000). Seedless grapes represent $25 \%$ of the fine table grapes exported by producers of the São Francisco Valley. They occupy approximately 2,500 ha of irrigated areas and this number tends to increase in the next years.

Although many studies regarding the effects of organic versus conventional systems on soil microbial dynamic have been conducted (Mäder et al., 2000; Purin et al., 2006), none has been performed on seedless grape crops under the semiarid conditions of Northeast Brazil. Beneficial effects of the mycorrhization in vineyards have been registered (Matsuoka et al., 2002; Schreiner, 2003; Cheng and Baumgartner, 2004) and are mainly related with improvement of the nutritional status of young plants during the nursery period (Matsuoka et al., 2002; Schreiner, 2003; Aguín et al., 2004; Cheng and Baumgartner, 2004) or during acclimatization of micropropagated plants. Among the factors that impact the AMF-plant association the plant genotype is one of the most important. This justifies studies to explore the importance of AMF for the seedless variety of grape (Miyauchi et al., 2008). We tested the hypothesis that areas of seedless grapes under treatment with organic manure have higher microbial population and higher AMF activity when compared to areas under conventional management. This study was conducted to evaluate the effect of organic versus conventional cultivation on soil microbial and AMF activity in seedless grape crops.

\section{Material and Methods}

The study was conducted on a commercial seedless grape farm in Petrolina (09 $19^{\prime}$ S, 40 $21^{\prime}$ W), Pernambuco State, Brazil. The climate of the region is semiarid (type Bswh Köeppen). Average air temperature is $26^{\circ} \mathrm{C}$, with $50 \%$ of relative air humidity, $450 \mathrm{~mm}$ annual precipitation and $3000 \mathrm{~h} /$ year of sunshine. Soil is classified as Typic Quartzipsamments (Soil Survey Staff, 1999) or Neossolo Quartzarênico (Empresa Brasileira de Pesquisa Agropecuária, 2006). Plots were planted with the seedless grape cultivar "Festival seedless/IAC 766 rootstock". Two areas with approximately ten years old vineyards were chosen: (i) one fertilized according to recommendations for the crop in the region, characterized as conventional (Pereira et al., 2000); (ii) one receiving a compost of plant debris (organic amendment) during the last three years, characterized as organic. Both, the organic and conventionally fertilized vineyards were daily irrigated through microsprinkling.

Samples were collected during the harvest phase of the second production cycle. Ten compound samples were randomly collected from each area. Each compound sample consisted of four sub-samples taken from equidistant points around each plant. Soil and roots were collected from the 20 top centimeters in each sampling point. Roots samples were kept at $4^{\circ} \mathrm{C}$ until evaluations of mycorrhizal colonization were performed. Part of the soil samples was used for physical and chemical characterization (Table 1). Another fraction (200 $\mathrm{mL}$ per container) was used for preparing trap cultures. The remaining of the soil samples was kept at $4^{\circ} \mathrm{C}$ before being used for evaluation of mycorrhizal variables and soil biochemical and microbial activity.

AMF spores were extracted from soil by wet sieving and sucrose centrifugation (Gerdemann and Nicolson, 1963; Jenkins, 1964) and counted under a dissecting microscope. The quantity of AMF spores was expressed as number of spores per gram of soil. Seedless grape roots were treated with $10 \% \mathrm{KOH}$ and stained with Chlorazol Black - E 0.03\% (Brundrett et al., 1984).The mycorrhizal colonization was evaluated by the gridline intersect method (Giovanetti and Mosse, 1980).

Table 1 - Chemical and physical characterization of a typic Quartzipsamments or Neossolo Quartzarênico collected from the rhizosphere of apirenic grapeyards (IAC 766/Festival Seedless) cultivated under organic and conventional systems.

\begin{tabular}{lcccccccc}
\hline Sy stem & $\mathrm{OM}$ & $\mathrm{pH}^{*}$ & $\mathrm{EC}$ & $\mathrm{P}$ & $\mathrm{CEC}$ & Sand & Silt & Clay \\
\hline & $\mathrm{g} \mathrm{dm}^{-3}$ & & $\mathrm{dS} \mathrm{m}^{-1}$ & $\mathrm{mg} \mathrm{dm}^{-3}$ & $\mathrm{mmol}_{\mathrm{c} \mathrm{dm}^{-3}}$ & & $\mathrm{~g} \mathrm{~kg}^{-1}$ & \\
Organic & 25.0 & 6.9 & 0.31 & 543 & 7.62 & 920 & 50 & 30 \\
Conventional & 6.21 & 7.0 & 1.37 & 135 & 3.39 & 940 & 30 & 30 \\
\hline
\end{tabular}

$\mathrm{OM}$ - organic matter; ${ }^{*} \mathrm{H}_{2} \mathrm{O}(1: 2.5)$; E.C. - electrical conductivity; CEC - cation exchange capacity. 
The most probable number of AMF propagules was determined by the Feldmann and Idczak (1994) method. Corn seeds were sown in pots with soil taken from the field diluted in sand $\left(0,10^{-1}, 10^{-2}, 10^{-3}\right)$. Pots were daily watered and maintained in a greenhouse during 30 days. After that, presence of mycorrhizal colonization was assessed in roots stained as mentioned above and the MPN of propagules was estimated in $\mathrm{cm}^{-3}$ of soil using the Cochran (1950) table.

To quantify Easily Extractable Bradford-related soil protein (EE-BRSP), soil aggregates were mechanically separated in two fractions: $<1 \mathrm{~mm}$ and $1-2 \mathrm{~mm}$ were collected. EEBRSP of each fraction was extracted from $0.25 \mathrm{~g}$ soil with $20 \mathrm{mM}$ citrate $\mathrm{pH} 7.0$ at $121^{\circ} \mathrm{C}$ for $30 \mathrm{~min}$, as described by Wright and Upadhaya (1998). Protein in the supernatant was determined by the Bradford dye binding assay using bovine serum albumin as standard (Bradford, 1976).

Trap cultures were established with the objective of increasing detection of species that may not have been sporulating when field samples were collected (Stutz and Morton, 1996). Trap cultures were established in $250 \mathrm{~mL}$ containers using only soil samples from the field. Sorghum [Sorghum bicolor (L.) Moench, cv. IPA 1011] was the host plant. Pots were maintained under greenhouse conditions at $25 \pm 3^{\circ} \mathrm{C}$; $75 \%$ relative humidity, 250 to $560 \mu \mathrm{mol} \mathrm{m} \mathrm{m}^{-1}$ luminosity. Soil samples were taken from the pots at the $45^{\text {th }}, 90^{\text {th }}$, and $135^{\text {th }}$ day after establishment of the cultures and the spores extracted for species identification. Spores were mounted onto microscope slides with PVLG (polyvynil alcohol lactoglycerol) and PVLG + Melzer (1:1). Species were identified based on Schenck and Pérez (1990), data from the International Culture Collection of Arbuscular Mycorrhizal Fungi (http://www.invam.caf.wvu.edu/taxonomy) and more recent publications.

Microbial biomass carbon (C-MB): carbon was estimated by fumigation with chloroform free of ethanol in $20 \mathrm{~g}$ of soil, followed by extraction of carbon with $50 \mathrm{~mL}$ of $0.5 \mathrm{M}$ $\mathrm{K}_{2} \mathrm{SO}_{4}$ and oxidation with $2 \mathrm{~mL}$ of $0.66 \mathrm{mM} \mathrm{K}_{2} \mathrm{Cr}_{2} \mathrm{O}_{7}$ in a medium with $10 \mathrm{~mL}$ of concentrated $\mathrm{H}_{2} \mathrm{SO}_{4}$ and $5 \mathrm{~mL}$ of concentrated $\mathrm{H}_{3} \mathrm{PO}_{4}$. Carbon was quantified by titration with $\mathrm{FeSO}_{4}\left(\mathrm{NH}_{4}\right)_{2} \mathrm{SO}_{4} \cdot 6 \mathrm{H}_{2} \mathrm{O}\left(0.033 \mathrm{eq} \mathrm{g} \mathrm{L}{ }^{-1}\right)$ using $\left(\mathrm{C}_{6} \mathrm{H}_{5}\right)_{2} \mathrm{NH}$ $(1 \%)$ as indicator. Calculations were performed in fumigated and non fumigated soil samples, using the correction factor

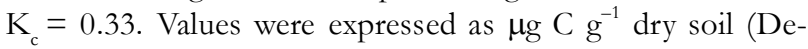
Polli and Guerra, 1997).

To calculate microbial respiration (C-CO $\mathrm{CO}_{2}$ evolution): 100 $\mathrm{g}$ of soil were incubated in $1000 \mathrm{~mL}$ recipients with $10 \mathrm{~mL}$

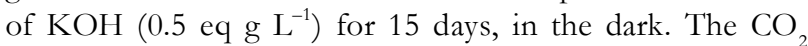
captured by $\mathrm{KOH}$ solution was quantified by titration with 0.1 eq $\mathrm{g} \mathrm{L}^{-1} \mathrm{HCl}$, using phenolphthalein $(0.1 \%$ in ethanol) and methyl orange $(1 \%)$ as $\mathrm{pH}$ indicators. The $\mathrm{CO}_{2}$ carbon liberated by microorganism respiration was expressed as $\mu \mathrm{g}$ $\mathrm{CO}_{2} \mathrm{~g}^{-1}$ of dry soil day ${ }^{-1}$ (Grisi, 1978). The metabolic coefficient $\left(q \mathrm{CO}_{2}\right)$ was determined by the relation between the carbon of the evoluted $\mathrm{CO}_{2}$ and the carbon of the soil microbial biomass.

To evaluate hydrolysis of fluorescein diacetate activity (FDA), $5 \mathrm{~g}$ of soil samples were incubated in an Erlenmeyer flask with $20 \mathrm{~mL}$ potassium phosphate buffer $(66 \mathrm{mM}$; $\mathrm{pH}$
7.6) and $200 \mu \mathrm{L}$ of FDA solution $\left(0.02 \mathrm{~g} 10^{-1} \mathrm{~mL}\right.$ acetone $)$ for $20 \mathrm{~min}$. The reaction was interrupted by addition of 20 $\mathrm{mL}$ acetone and measurements were taken using a spectrophotometer $(490 \mathrm{~nm})$. Increasing concentrations of FDA that were previously hydrolyzed by heat $\left(100^{\circ} \mathrm{C}\right)$ were used to construct a standard curve. The enzymatic activity was expressed in $\mu \mathrm{g}$ of hydrolyzed flourescein $\mathrm{g}^{-1}$ dry soil $\mathrm{h}^{-1}$ (Swisher and Carrol, 1980).

Data were submitted to one-way analysis of variance (ANOVA) and means were separated followed by the Tukey test $(0.05 \%)$. Data transformation were applied to the percentage of colonization (Arc Sen $\sqrt{x} / 100$ ) and to the number of AMF spores $\left(V_{x}+1\right)$ before statistical analysis.

\section{Results and Discussion}

The highest sporulation in field samples was observed in the organic system (Table 2). This may be due to the increase of organic matter in the soil under organic cultivation (Mohammad et al., 2003), considering that use of organic sources increases the abundance of AMF (Noyd et al., 1996). The organic input improves the physical and chemical soil properties, the nutritional status of the plant and, consequently, the amount of photosynthate for the fungus, which increase sporulation. Oehl et al. (2004) also observed higher number of spores in a soil from organic crops as compared to a soil with chemical fertilization. They attributed this difference to the excessive amount of applied mineral fertilizers. It is possible that fertilization had effects on sporulation in the areas chosen for the present experiment. However, we can only speculate on factors such as the quantity and nature of fertilizers since a more precise evaluation was not the objective of this study.

Mycorrhizal colonization was relatively low in both systems (Table 2) when compared to colonization rates higher than $80 \%$ which have been reported in vineyards (Schreiner, 2003). Root colonization was three times higher in the organic system $(15.9 \%)$ when compared to the conventional system (4.7\%). Increased AMF root colonization is one of the benefits of organic cultivation that has been also reported in other crops. Roots of Secale cereale L. (rye) under organic management presented $77 \%$ of mycorrhizal colonization, while in the conventional system this percentage was reduced to $11 \%$ (Sattelmacher et al., 1991). Levels of mycorrhizal colonization from 0 to $45 \%$ in vineyards (conventional) were observed by Matsuoka et al. (2002) who attributed these levels to the intensive use of chemical fertilizers and stage of plant development. Plants also have different colonization patterns and mycorrhizal dependency, and this variation is also observed in grapes. Mycorrhizal root colonization ranged between 46 to $76 \%$ according to the rootstock (Karagiannidis et al., 1997). Likewise, the low values of root colonization observed in this study may be typical of the variety used (IAC 766/Festival Seedless). We quantified 110 and 79 infective propagules of $\mathrm{AMF} \mathrm{cm}^{3}$ soil in the organic and conventional cultivation systems, respectively. Our data corroborates previous studies carried out with other economically important species such as Spinacea oleraceae and Malus domestica (Douds Jr. et al., 1997; Purin et al., 2006). 
Table 2 - Number of AMF spores, most probable number of AMF propagules (MPN), easily extractable Bradfordrelated soil protein glomalin (EE-BRSP) and arbuscular mycorrhizal colonization (MC) in the rhizosphere of grape rootstocks (IAC 766/Festival Seedless), produced under organic and conventional systems.

\begin{tabular}{|c|c|c|c|c|c|}
\hline \multirow{2}{*}{ System } & \multirow{2}{*}{ Number of AMF spores } & \multirow{2}{*}{ MPN of AMF propagules } & \multicolumn{2}{|c|}{ EE-BRSP } & \multirow{2}{*}{ MC } \\
\hline & & & $(1-2 \mathrm{~mm})$ & $(<1 \mathrm{~mm})$ & \\
\hline & $50 \mathrm{~g}^{-1}$ soil & $\mathrm{cm}^{-3}$ soil & \multicolumn{2}{|c|}{----- mg g soil-1 ${ }^{-1}$ aggregates ----- } & $\%$ \\
\hline Organic & $12.00 \mathrm{a}$ & 110 & $2.52 \mathrm{a}$ & $1.33 \mathrm{a}$ & $15.9 \mathrm{a}$ \\
\hline Conventional & $4.00 \mathrm{~b}$ & 79 & $2.44 \mathrm{a}$ & $1.37 \mathrm{a}$ & $4.7 \mathrm{~b}$ \\
\hline
\end{tabular}

Means followed by the same letters, in the column, do not differ (Tukey test, $p<0.05$ ).

EE-BRSP has been positively related to the increase of fertility (Lovelock et al., 2004a) and carbon levels (Wright and Upadhyaya, 1998; Lovelock et al., 2004a). However, the organic cultivation of grapes did not increase EE-BRSP production when compared with the conventional system (Table 2). It is possible that only three years of organic management are not enough to show differences in the quantities of EE-BRSP. All nutrient dynamics in soil are reflected first on components directly involved in mycorrhization, such as spores and root colonization, with changes in protein turnover being observed in long term studies. Also, there are differences on AMF composition between organic and conventional systems and the species probably differ regarding their capability to produce the EE-BRSP. This means that differences cannot be related only to soil management, but also to the microbial composition. Besides, the high levels of $\mathrm{P}$ commonly observed in soils under organic management can inhibit EE-BRSP production (Lovelock et al., 2004b). Differences of EE-BRSP quantities between organic and conventional management also depend on the stage of plant growth (Monokrousos et al., 2008).

Altogether, thirteen AMF taxa were identified in the two crop systems. Twelve species were detected in the organic systems, and nine were detected in the conventional (Table 3). Eight of the 13 species were found in both systems. Previous studies conducted in the Brazilian semiarid registered variable number of AMF species. Maia and Trufem (1990) identified only eight AMF species associated with cotton, bean, corn and cassava crops. Fifteen AMF species were identified in association with banana at the São Francisco Submedium Valley (Yano-Melo et al., 1997). Twenty four species of AMF have been registered in a semiarid area with native vegetation known as "caatinga" (Souza et al., 2003). These numbers suggest that in this region of Brazil the number of AMF species decreases when native vegetation is removed and crop species are introduced. The establishment of the vineyard also affected the AMF native population; successive monoculture usually reduces the number of AMF species (Douds and Millner, 1999). Because of this negative impact, it is important to adopt cultivation systems that minimize the loss of AMF species. The present study confirms the organic fertilization as a practice of this nature.

The species Acaulospora excavata, Entrophospora infrequens, Glomus sp.3 and Scutellospora sp. were found only in the organically managed area. Scutellospora gregaria was observed only in soil with conventional system. Some species such as A. mellea, G. sinuosum and G. etunicatum were always detected throughout evaluation of the trap cultures. Other species such as $A$. scrobiculata were observed only after 90 days of trap pot culturing (Table 3). E. infrequens and $G$. albida were identified only with the use of trap cultures in soil with organic fertilizer.

Higher microbial activity was observed in the organic system than in the conventional system (Table 4). This might have resulted from the higher amount of substrates with potential for microbial degradation, which were used as energy and carbon source by the soil microbiota (Fernandes et al., 2005). The soil from the organic system presented an evolution of $59.64 \mu \mathrm{g}$ C- $\mathrm{CO}_{2} \mathrm{~g}^{-1}$ dry soil day ${ }^{-1}$ (Table 4). This value is twofold higher than what was observed in the conventional system. Similar results were obtained by Sarangi et al. (2001) who registered an increase of $143 \%$ in $\mathrm{CO}_{2}$ emission in a soil with organic amendment $\left(17.5 \mathrm{t}\right.$ residue $\left.\mathrm{ha}^{-1}\right)$ when compared to the treatment with chemical fertilizers (N:P:K 80:40:40 $\mathrm{kg} \mathrm{h}^{-1}$ ). Possibly, the compost used in the organic cultivation of grapes increases soil microbial activity. In general, addition of organic materials enhances respiratory activity because the organic residues are energetic substrates consumed during oxidative metabolism of the soil heterotrophic microbiota (Bhattacharyya et al., 2001). The carbon of the microbial biomass (C-MB) is one of the most important variables that reflect differences between organic and conventional areas (Monokrousos et al., 2006). This was confirmed in the present study. The C-BM values were higher in the organic system than in the conventional area, reflecting differences on the microbial communities.

Other indicators of microbial activity were also higher in the organic areas when compared to the conventional areas. There was a two-fold increase in carbon of microbial biomass and a three-fold increase in FDA activity (Table 4). These differences may be due to the higher levels of organic matter in the organic system (Haynes, 1999; Taylor et al., 2002). The organic amendment introduced in the vineyards probably presented more metabolically active microorganisms that contributed for higher enzymatic activity in this system (Debosz et al., 2002). The enzymes that adhere to the colloids of the organic compost can be another factor to increase the rate of FDA hydrolysis in the organic cultivation (Nannipieri et al., 2003). Organic fertilizers may also contribute to modify root exudates in the vineyards, by increasing the amount of organic compounds produced by the plant, 
Table 3 - Taxa of AMF in soils with organic and conventional crops of vineyards (IAC 766/Festival Seedless) identified through direct exam of field material and after maintenance of soil samples in trap cultures, evaluated at the $45^{\text {th }}, 90^{\text {th }}$ and $135^{\text {th }}$ day of established.

\begin{tabular}{|c|c|c|c|c|c|c|c|c|}
\hline \multirow{3}{*}{ Species of AMF } & \multicolumn{2}{|c|}{ Field } & \multicolumn{6}{|c|}{ After trap culture } \\
\hline & \multirow[t]{2}{*}{$\mathrm{OC}$} & \multirow[t]{2}{*}{$\mathrm{CC}$} & \multicolumn{3}{|c|}{ OC } & \multicolumn{3}{|c|}{$\mathrm{CC}$} \\
\hline & & & 45 & 90 & 135 & 45 & 90 & 135 \\
\hline Acaulospora mellea Spain \& Schenck & $\mathrm{x}$ & $\mathrm{x}$ & $\mathrm{x}$ & $\mathrm{x}$ & & $\mathrm{x}$ & $\mathrm{x}$ & $\mathrm{x}$ \\
\hline A. scrobiculata Trappe & $\mathrm{x}$ & $\mathrm{x}$ & & $\mathrm{x}$ & $\mathrm{x}$ & & $\mathrm{x}$ & $\mathrm{x}$ \\
\hline A. excavata Ingleby \& Walker & $\mathrm{x}$ & & & $\mathrm{x}$ & $\mathrm{x}$ & & & \\
\hline Entrophospora infrequens (Hall) Ames \& Schneid. & & & & $\mathrm{x}$ & & & & \\
\hline Gigaspora albida Schenck \& Sm. & & $\mathrm{x}$ & & $\mathrm{x}$ & & & & $\mathrm{x}$ \\
\hline Glomus sinuosum (Gerd. \& Bakshi) Almeida \& Schenck & $\mathrm{x}$ & $\mathrm{x}$ & & $\mathrm{x}$ & $\mathrm{x}$ & $\mathrm{x}$ & $\mathrm{x}$ & $\mathrm{x}$ \\
\hline G. etunicatum Becker \& Gerd. & $\mathrm{x}$ & $\mathrm{x}$ & $\mathrm{x}$ & $\mathrm{x}$ & $\mathrm{x}$ & $\mathrm{x}$ & $\mathrm{x}$ & $\mathrm{x}$ \\
\hline Glomus sp.1 & $\mathrm{x}$ & $\mathrm{x}$ & & & & $\mathrm{x}$ & $\mathrm{x}$ & $\mathrm{x}$ \\
\hline Glomus sp.2 & $\mathrm{x}$ & $\mathrm{x}$ & $\mathrm{x}$ & $\mathrm{x}$ & & & & \\
\hline Glomus sp. 3 & $\mathrm{x}$ & & & & & & & \\
\hline Glomus sp.4 & $\mathrm{x}$ & $\mathrm{x}$ & & & & & $\mathrm{x}$ & $\mathrm{x}$ \\
\hline Scutellospora gregaria (Schenck \& Nicolson) Walker \& Sanders & & $\mathrm{x}$ & & & & & & \\
\hline Scutellospora sp.1 & $\mathrm{x}$ & & & & & & & \\
\hline Total number of species & 10 & 9 & 3 & 8 & 4 & 4 & 6 & 7 \\
\hline
\end{tabular}

OC - organic crop; CC - conventional crop.

Table 4 - Carbon of microbial biomass (C-MB), microbial respiration $\left(\mathrm{C}-\mathrm{CO}_{2}\right)$, FDA hydrolysis and metabolic coefficient $\left(q \mathrm{CO}_{2}\right)$ in the rhizosphere of vineyards rootstocks (IAC 766/Festival Seedless), under organic and conventional systems.

\begin{tabular}{lcccc}
\hline Crop sy stem & $\mathrm{C}-\mathrm{MB}$ & ${\mathrm{C}-\mathrm{CO}_{2}}$ & FDA & ${q \mathrm{CO}_{2}}$ \\
\hline & $\mu \mathrm{gg} \mathrm{dry} \mathrm{soil}{ }^{-1}$ & $\mu \mathrm{ggdry} \mathrm{soil}{ }^{-1} \mathrm{~d}^{-1}$ & $\mu g \mathrm{gdry} \mathrm{soil}{ }^{-1} \mathrm{~h}^{-1}$ & \\
Organic & $163.41 \mathrm{a}$ & $59.64 \mathrm{a}$ & $24.63 \mathrm{a}$ & $0.365 \mathrm{a}$ \\
Conventional & $65.98 \mathrm{~b}$ & $19.86 \mathrm{~b}$ & $6.56 \mathrm{~b}$ & $0.301 \mathrm{a}$ \\
\hline
\end{tabular}

Means followed by the same letters, in the column, do not differ (Tukey test, $p<0.05$ ).

maximizing soil microbial activity (Pascual et al., 1999). In addition, we hypothesize that higher AMF sporulation and MPN values observed in the organic system likely contributed to increase the microbial biomass carbon in this management system. It is possible that production of extraradical mycelial net was also increased by the organic system and contributed to the $\mathrm{C}$ stock in the soil and affecting soil aggregation (Rillig et al., 2001).

The metabolic coefficient $\left(q \mathrm{CO}_{2}\right)$ did not differ between the systems (Table 4). High values of $q \mathrm{CO}_{2}$ usually may indicate a stressing condition in disturbed systems (Garcia et al., 2002) and, in general, conventional agrosystems present higher values in relation to the organic cultivation or the natural ecosystems (Dilly and Munch, 1998). However, not always the $q \mathrm{CO}_{2}$ is sensible to measure the soil conditions (Wardle and Ghani, 1995). In semiarid soils, higher $q \mathrm{CO}_{2}$ was registered in a native area compared with an irrigated area receiving saline waste (Pereira et al., 2004) and increase of $q \mathrm{CO}_{2}$ in revegetated semiarid areas was also observed (Garcia et al., 2005). Other variables may be more sensible to indi- cate the soil quality, as shown in this study. Thus, other relations based on microbiological variables, should be evaluated to elucidate the general microbial activity of a soil, as $q \mathrm{CO}_{2}$ does not have universal values.

The organic cultivation of seedless grapes increased AMF and microbial activity as well as contribute to carbon immobilization by microorganisms in a short period of time. Evidence from this study supports organic management as a potential alternative to produce table grapes in the Brazilian semiarid region.

\section{Acknowledgements}

The authors acknowledge the Empresa Brasileira de Pesquisa Agropecuária (EMBRAPA Semi-árido) for logistic support, the Conselho Nacional de Desenvolvimento Científico e Tecnológico $(\mathrm{CNPq})$ and the Coordenação de Aperfeiçoamento de Pessoal de Nível Superior (Capes) for providing financial support and scholarships N.O. Freitas and F. S.B. Silva, and a fellowship to L.C. Maia. Thanks are also due 
to Dr. David Bousfield for revising the English version and to the anonymous reviewers for the extremely useful suggestions.

\section{References}

Aguín, O.; Mansilla, J.P.; Vilariño, A.; Sainz, M.J. 2004. Effects of mycorrhizal inoculation on root morphology and nursery production of three grapevine rootstocks. American Journal of Enology and Viticulture 55: 108-111.

Anaya, A.L. 1999. Allelopathy as tool in the management of biotic resources in agroecosystems. Critical Reviews in Plant Sciences 18: 697-739.

Bengtsson, J.; Ahnström, J.; Weibul, A.N. 2005. The effects organic agriculture on biodiversity and abundance: a meta-analysis. Journal of Applied Ecology 42: 261-269.

Bettiol, W.; Ghini, R.; Galvão, A.H.G.; Ligo, M.A.V.; Mineiro, J.L.C. 2002. Soil organisms in organic and conventional cropping systems. Scientia Agricola 59: 565-572.

Bhattacharyya, P.; Pal, R.; Chakraborty, A.; Chakrabarti, K. 2001. Microbial biomass and activity in lateritic soil amended with municipal solid waste compost. Journal of Agronomy and Crop Science 187: 207-211.

Bradford, M.M. 1976. A rapid and sensitive method for the quantification of microgram quantities of protein utilizing the principle of proteindye binding. Analytical Biochemistry 72: 248-254.

Brundrett, M.C; Piché, Y.; Peterson, R.L. 1984. A new method for observing the morphology of vesicular-arbuscular mycorrhizae. Canadian Journal of Botany 62: 2128-2134.

Cheng, X.; Baumgartner, K. 2004. Survey of arbuscular mycorrhizal fungal communities in northern California vineyards and mycorrhizal colonization potencial of grapevine nursery stock. Hortscience 39: 1702-1706.

Cochran, W.G. 1950. Estimation of bacterial densities by means of the most problable number. Biometrics 6: 105-116.

Debosz, K.; Petersen, S.O.; Kure, L.K.; Ambus, P. 2002. Evaluating effects of sewage sludge and household compost on soil physical, chemical and microbiological properties. Applied Soil Ecology 19: $237-248$

De-Polli, H.; Guerra, J.G.M. 1997. Determination of C of the Soil Microbial Biomass: Method of Fumigation-Extraction. EmbrapaCNPAB, Seropédica, RJ, Brazil. (in Portuguese).

Dilly, O.; Munch, J.C. 1998. Ratios between estimates of microbial biomass content and microbial activity in soils. Biology and Fertility of Soils 27: 374-379.

Douds Jr., D.D.; Galvez, L.; Franke-Snyder, M.; Reider, C.; Drinkwater, L.E. 1997. Effect of compost addition and crop rotation point upon VAM fungi. Agriculture, Ecosystems \& Environment 65: 257-266.

Douds Jr., D.D.; Millner, P.D. 1999. Biodiversity of arbuscular mycorrhizal fungi in agroecosystems. Agriculture, Ecosystems \& Environment 74: 77-93.

Empresa Brasileira de Pesquisa Agropecuária [EMBRAPA]. 2006. Sistema Brasileiro de Classificação de Solos. 2ed. Sistema Brasileiro de Classificação de Solos. Brasília, DF, Brazil. (in Portuguese).

Feldmann, F; Idczak, E. 1994. Inoculum production of vesiculararbuscular mycorrhizal fungi for use in tropical nurseries. p. 799817. In: Norris, J.R.; Read, D.; Varma, A.K., eds. Techniques for Mycorrhizal Research. Academic Press, London, UK.

Fernandes, S.A.P.; Bettiol, W.; Cerri, C.C. 2005. Effects of sewage sludge on microbial biomass, basal respiration, metabolic quotient and soil enzymatic activity. Applied Soil Ecology 30: 65-77.

Garcia, C.; Hernandez, T.; Roldan, A.; Martin, A. 2002. Effect of plant cover decline on chemical and microbiological parameters under mediterranean climate. Soil Biology \& Biochemistry 34: 635-642

Garcia, C.; Roldan, A.; Hernandez, T. 2005. Ability of different plant species to promote microbiological process in semiarid soil Geoderma 124: 193-202.
Grisi, B.M. 1978. The chemical method of the measurement of soil respiration. Ciência e Cultura 30: 82-88 (in Portuguese, with abstract in English).

Gerdemann, J.W.; Nicolson, T.H. 1963. Spores of mycorrhizal Endogone species extracted from soil by wet sieving and decanting. Transactions of the British Mycological Society 46: 235-244.

Giovanetti, M.; Mosse, B. 1980. An evaluation of techniques for measuring vesicular arbuscular mycorrhizal infection in roots. New Phytology 84: 489-500.

Haynes, R.J. 1999. Size and activity of the soil microbial biomass under grass and arable management. Biology and Fertility of Soils 30: 210-216.

Jeffries, P.; Gianinazzi, S.; Perotto, S.; Turnau, K.; Barea, J.M. 2003. The contribution of arbuscular mycorrhizal fungi in sustainable maintenance of plant health and soil fertility. Biology and Fertility of Soils 37: 1-16.

Jenkins, W.R. 1964. A rapid centrifugal-flotation technique for separating nematodes from soil. Plant Disease Report 48: 692.

Karagiannidis, N.; Velemis, D.; Stavropoulos, N. 1997. Root colonization and spore population by VA-mycorrhizal fungi in four grapevines rootstocks. Vitis 36: 57-60.

Lovelock, C.E.; Wright, S.F.; Nichols, K.A. 2004a. Using glomalin as an indicator for arbuscular mycorrhizal hyphae growth: an example from a tropical rain forest soil. Soil Biology and Biochemistry 36: 1009-1012.

Lovelock, C.E.; Wright, S.F.; Clarck, D.A.; Ruess, R.W. 2004b. Soil stocks of glomalin produced by arbuscular mycorrhizal fungi across a tropical rain forest landscape. Journal of Ecology 92: 278-287.

Mäder, P.; Edenhofer, S.; Boller, T.; Wiemken, A.; Niggli, U. 2000. Arbuscular mycorrhizae in a lon-term field trial comparing lowinput (organic, biological) and high-input (conventional) farming systems in a crop rotation. Biology and Fertility of Soils 31: 150156.

Maia, L.C.; Trufem, S.F.B. 1990. Vesicular-arbuscular mycorrhizal fungi in cultivated soils in Pernambuco State, Brazil. Revista Brasileira de Botânica 13: 89-95 (in Portuguese with abstract in English).

Marshall, V.G. 2000. Impacts of forest harvesting on biological processes in northern forest soils. Forest Ecology and Management 133: $43-60$.

Matsuoka, M.; Saggin Jr., O.J.; Loureiro, M.F. 2002 Arbuscular mycorrhizal fungi in grape production in systems Primavera do Leste, Region Mato Grosso State-Brazil. Revista Agricultura Tropical 6: 113-134 (in Portuguese with abstract in English).

Miyauchi, M.Y.H.; Lima, D.S.; Nogueira, M.A.; Lovato, G.M.; Murate, L.S.; Cruz, M.F.; Ferreira, J.M.; Zangaro, W.; Andrade, G. 2008 Interactions between diazotrophic bacteria and mycorrhizal fungus in maize genotypes. Scientia Agricola 65: 525-531.

Mohammad, M.J.; Hamad, S.R.; Malkawit, H.I. 2003. Populations of arbuscular mycorrhizal fungi in semi-arid environment of Jordan as influenced by biotic and abiotic factors. Journal of Arid Environments 53: 409-417.

Monokrousos, N.; Papatheodorou, E.M.; Diamantopoulos, J.D.; Stamou, G.P. 2006. Soil quality variables in organically and conventionally cultivated field sites. Biology and Fertility of Soils 38: 1282-1289.

Monokrousos, N.; Papatheodorou, E.M.; Stamou, G.P. 2008. The response of soil biochemical variables to organic and conventional cultivation of Asparagus sp. Soil Biology \& Biochemistry 40: 198206

Nannipieri, P.; Ascher, J.; Ceccherini, M.T.; Landi, L.; Pietramellara, G.; Renella, G. 2003. Microbial diversity and soil functions. European Journal of Soil Science 54: 655-670.

Noyd, R.K.; Pfleger, F.L.; Norland, M.R. 1996. Field responses to added organic matter, arbuscular mycorrhizal fungi, and fertilizer in reclamation of taconite iron one tailing. Plant and Soil 179: 8997.

Oehl, F.; Sieverding, E.; Mäder, P.; Dubois, D.; Ineichen, K.; Boller, T. Wiemken, A. 2004. Impact of long-term conventional and organic farming on the diversity of arbuscular mycorrhizal fungi. Oecologia 138: $574-583$ 
Pascual, J.A.; García, C.; Hernández, T. 1999. Comparison of fresh and composted organic waste in their efficacy for the improvement of arid soil quality. Bioresource Technology 68: 255-264.

Pereira, J.R.; Faria, C.M.B.; Silva, D.J.; Soares, J.M. 2000. Nutrition and fertilizing of vineyards. p. 213-257. In: Leão, P.C.S.; Soares, J.M., eds. The viticulture in the Brazilian Semi-Arid: Petrolina, PE, Brazil. (in Portuguese).

Pereira, S.V.; Martinez, C.R.; Porto, E.R.; Oliveira, B.R.B.; Maia, L.C. 2004. Microbial activity in a semiarid soil cultivated with Atriplex nummularia. Pesquisa Agropecuária Brasileira 39: 757-762 (in Portuguese with abstract in English).

Purin, S.; Klauberg-Filho, O.; Sturmer, S.L. 2006. Mycorrhizae activity and diversity in conventional and organic and apple orchards from Brazil. Soil Biology and Biochemistry 38: 1831-1839.

Rillig, M.C.; Wright, S.F.; Nichols, K.A.; Schmidt, W.F.; Torn, M.S. 2001. Large contribution of arbuscular mycorrhizal fungi to soil carbon pools in tropical forest soils. Plant and Soil 233: 167-177.

Ryan, M.H.; Small, D.R.; Ash, J.E. 2000. Phosphorus controls the level of colonization by arbuscular mycorrhizal fungi in conventional and biodynamic irrigated dairy pastures. Australian Journal of Experimental Agriculture 40: 663-670.

Ryan, M.H.; Graham, J.H. 2002. Is there a role for arbuscular mycorrhizal fungi in production agriculture? Plant and Soil 244: 263-271.

Sampaio, D.B.; Araújo, A.S.F.; Santos, V.B. 2008. Evaluation of biological indicators of soil quality under conventional and organic fruit farming system. Ciência e Agrotecnologia 32: 353-359. (in Portuguese with abstract in English).

Sattelmacher, B.; Reinhard, S.; Pomikako, A. 1991. Differences in mycorrhizal colonization of rye (Secale cereale L.) grown in conventional or organic (biological-dynamic) farming systems. Journal of Agronomy and Crop Sciences 167: 350-355.

Sarangi, P.K.; Mahakur, D.; Mishra, P. 2001. Soil biochemical activity and growth response of rice Oryza sativa in flyash amended soil. Bioresource Technology 76: 199-205.

Schenck, N.C.; Pérez, Y. 1990. Manual for the identification of VA mycorrhizal fungi.: Gainesville, FL, USA. (Synergistic Publications).

Schreiner, R.P. 2003. Mycorrhizal colonization of grapevine rootstocks under field conditions. American Journal of Enology and Viticulture 54: 143-148.

Silva, P.C.G.; Correia, R.C. 2000. Social and economic characterization of the vineyard. p.1. In: Leão, P.C.S., Soares, J.M., eds. The viticulture at the Brazilian Semi-Arid. Embrapa Semi-Árido: Petrolina, PE, Brazil. (in Portuguese).
Souza, R.G.; Maia, L.C.; Sales, M.F.; Trufem, S.F.B. 2003. Diversity and infectivity potential of arbuscular mycorrhizal fungi in na area of "caatinga" in the Xingó Region, State of Alagoas, Brazil. Revista Brasileira de Botânica 26: 49-69. (in Portuguese with abstract in English).

Srivastava, R.; Roseti, D.; Sharma, A.K. 2007. The evaluation of microbial diversity in a vegetable based cropping system under organic farming practices. Applied Soil Ecology 36: 116-123.

Survey Staff. 1999. Soil Taxonomy: A Basic System of Soil Classification for Making and Interpreting Soil Surveys. 2.ed. USDA-NRCS, Washington, DC, USA. (Agriculture Handbook, 436.(in Portuguese).

Stutz, J.C.; Morton, J.B. 1996. Successive pot cultures reveal high species richness of arbuscular endomycorrhizal fungi in arid ecosystems. Canadian Journal of Botany 74: 1883-1889.

Swisher, R.; Carroll, G.C. 1980. Fluorescein diacetate hydrolysis as an estimator of microbial biomass on coniferous needle surfaces. Microbial Ecology 6: 217-226.

Taylor, J.P.; Wilson, B.; Mills, M.S.; Burns, R.G. 2002. Comparison of microbial members and enzymatic activities in surface soils and subsoils using various techniques. Soil Biology and Biochemistry 34: 387-401.

Truu, M.; Truu, J.; Ivask, M. 2008. Soil microbiological and biochemical properties for assessing the effect of agricultural management practices in Estonian cultived soils. European Journal of Soil Biology 44: 231-237.

Wardle, D.A.; Ghani, A. 1995. A critique of the microbial metabolic $\left(q \mathrm{CO}_{2}\right)$ as a bioindicator of disturbance and ecosystem development. Soil Biology and Biochemistry 27: 1601-1610.

Wright, S.F.; Upadhaya, A. 1998. A survey of soils for aggregate stability and glomalin, a glycoprotein produced by hyphae of arbuscular mycorrhizal fungi. Plant and Soil 198: 97-107.

Yano-Melo, A.M.; Maia, L.C.; Morgado, L.B. 1997. Arbuscular mycorrhizal fungi associated with roots of banana cultivated in the Submédio São Francisco Valley. Acta Botanica Brasilica 11: 115-121. (in Portuguese with abstract in English).

Received September 23, 2009

Accepted September 30, 2010 